Pacific Journal of Mathematics

UNIQUELY REPRESENTABLE SEMIGROUPS ON THE 


\title{
UNIQUELY REPRESENTABLE SEMIGROUPS ON THE TWO-CELL
}

\author{
J. T. Borrego, H. Cohen, ANd E. E. DeVun
}

\begin{abstract}
A semigroup $S$ is said to be uniquely representable in terms of two subsets $X$ and $Y$ of $S$ if $X \cdot Y=Y \cdot X=S, x_{1} y_{1}=$ $x_{2} y_{2}$ is a nonzero element of $S$ implies $x_{1}=x_{2}$ and $y_{1}=y_{2}$, and $y_{1} x_{1}=y_{2} x_{2}$ is a nonzero element of $S$ implies $y_{1}=y_{2}$ and $x_{1}=x_{2}$ for $x_{1}, x_{2} \in X$ and $y_{1}, y_{2} \in Y$. A semigroup $S$ is said to be uniquely divisible if for each $s \in S$ and every positive integer $n$ there exists a unique $z \in S$ such that $z^{n}=s$. Theorem. If $S$ is a uniquely divisible semigroup on the two-cell with the set of idempotents of $S$ being a zero for $S$ and an identity for $S$, then $S$ is uniquely representable in terms of $X$ and $Y$ where $X$ and $Y$ are iseomorphic copies of the usual unit interval and the boundary of $S$ equals $X$ union $Y$. Corollary. If $S$ is a uniquely divisible semigroup on the two-cell and if $S$ has only two idempotents, a zero and an identity, then the nonzero elements of $S$ form a cancellative semigroup.
\end{abstract}

A semigroup $S$ is said to be uniquely representable in terms of two subsets $X$ and $Y$ of $S$ if $X \cdot Y=Y \cdot X=S, x_{1} y_{1}=x_{2} y_{2}$ is a nonzero element of $S$ implies $x_{1}=x_{2}$ and $y_{1}=y_{2}$, and $y_{1} x_{1}=y_{2} x_{2}$ is a nonzero element of $S$ implies $y_{1}=y_{2}$ and $x_{1}=x_{2}$ for $x_{1}, x_{2} \in X$ and $y_{1}, y_{2} \in Y$. A semigroup $S$ is said to be uniquely divisible if for every $s \in S$ and every positive integer $n$ there exists a unique $z \in S$ such that $z^{n}=s$.

The primary purpose of this paper is to show that if $S$ is a uniquely divisible semigroup on two-cell with the set of idempotents of $S$ being a zero for $S$ and an identity for $S$, then $S$ is uniquely representable in terms of $X$ and $Y$ where $X$ and $Y$ are iseomorphic copies of the usual unit interval and the boundary of $S$ equals $X$ union $Y$. As a corollary to this theorem we shall prove a conjecture of $D$. R. Brown, that if $S$ is a uniquely divisible semigroup on the two-cell and if $S$ has only two idempotents, a zero and an identity, then the nonzero elements of $S$ form a cancellative subsemigroup of $S$.

Notation. Throughout $S$ will be a uniquely divisible semigroup on the two-cell with $E(S)$ (the set of idempotents of $S)=\{0,1\}$ where 0 is the zero for $S$ and 1 is the identity for $S$. It is well known that the boundary of $S$ is the union of two usual threads $X$ and $Y$ with $X \cap Y=\{0,1\}$ and $S=X \cdot Y=Y \cdot X$. Intervals containing $x$ will represent segments of $X$ and intervals with $y$ shall stand for segments of $Y$. For a positive integer $n, \mathrm{~s}^{1 / n}$ will denote the unique $n$th root of $s$ in $S$. 
The authors would like to thank the referee for pointing out the following result due to J. D. Lawson and M. Friedberg and which appears in [2].

LEMMA 1. If $T$ is a uniquely divisible semigroup with $E(T)=$ $\{0,1\}$, then $T$ has no zero divisors.

Proof. Suppose $a b=0$ for some $a, b \in T, a \neq 0$. Then $(b a)^{2}=b(a b) a$ $=0$, hence $b a=0$. Thus $0=a b=a^{1 / 2}\left(a^{1 / 2} b\right)=\left(a^{1 / 2} b\right) a^{1 / 2}=\left(a^{1 / 2} b\right)\left(a^{1 / 2} b\right)$, so $a^{1 / 2} b=0$. It follows that $a^{1 / 2^{n}} b=0$ for all $n$. Since $\left\{a^{1 / 2^{n}}\right\} \rightarrow 1, b=0$.

Define $f: X \times Y \rightarrow S$ onto $S$ by $f(x, y)=x y$. The proofs of the following three lemmas are analogous to the proofs in [3].

LEMMA 2. If $f\left(x_{1}, y_{1}\right)=f\left(x_{2}, y_{2}\right) \neq 0$, then either

(1) $x_{1}=x_{2}$ and $y_{1}=y_{2}$ or

(2) $x_{1}>x_{2}$ and $y_{2}>y_{1}$ or

(3) $x_{2}>x_{1}$ and $y_{1}>y_{2}$.

LEMmA 3. If $s \in S \backslash\{0\}$, then there exist $\left(x_{1}, y_{1}\right),\left(x_{2}, y_{2}\right) \in f^{-1}(s)$ such that for all $(x, y) \in f^{-1}(s)$ we have $x_{1} \geqq x \geqq x_{2}$ and $y_{2} \geqq y \geqq y_{1}$.

Lemma 4. If $\mathrm{s} \in S \backslash\{0\}$, then $\pi_{1}\left(f^{-1}(s)\right)$ is connected.

LEMma 5. If $s \in S \backslash\{0\}$, then $f^{-1}(s)$ is an arc.

Proof. Let $\left[x_{1}, x_{2}\right]=\pi_{1}\left(f^{-1}(s)\right)$, and define $h:\left[x_{1}, x_{2}\right] \rightarrow f^{-1}(s)$ by $h(x)=(x, y)$ where $y$ is the unique $y \in Y$ (lemma 2) such that $f(x, y)$ $=s$. Now $h:\left[x_{1}, x_{2}\right] \rightarrow f^{-1}(s)$ is a continuous, one-to-one, onto function. Thus $h:\left[x_{1}, x_{2}\right] \rightarrow f^{-1}(s)$ is a homeomorphism, and $f^{-1}(s)$ is an arc.

Definition 6. Let $J=\left\{(x, y):(x, y) \in X \times Y\right.$ and $f^{-1}(f(x, y))$ is not $a_{\Perp}^{\top}$ point\}.

Lemma 7. If $s \in f(J)$, then $X s=s Y$.

The proof of the above lemma is analogous to the proof of Lemma 10 of [3].

LEMmA 8. If $\left\{(x, y): 0 \leqq x<x_{0}, 0 \leqq y<y_{0}\right\} \subset J$, then $\{(x, y): 0 \leqq$ $\left.x \leqq x_{0}, 0 \leqq y \leqq y_{0}\right\} \backslash\left\{\left(x_{0}, y_{0}\right)\right\} \subset J$. Moreover, for each $\left(x^{\prime}, y^{\prime}\right) \in\{(x, y): 0 \leqq$ $\left.\left.x \leqq x_{0}, 0 \leqq y \leqq y_{0}\right\} \backslash\left\{x_{0}, y_{0}\right)\right\}$ there exists $\bar{x} \in X$ such that $f\left(\bar{x}, y_{0}\right)=f\left(x^{\prime}, y^{\prime}\right)$.

Proof. Let $x_{1} \in\left[0, x_{0}\right)$ and fix $x_{2} \in\left(x_{1}, x_{0}\right)$. Then for each $y \in\left[0, y_{0}\right)$ 
we have $\left(x_{2}, y\right) \in J$. Select an increasing sequence $\left\{z_{n}\right\}$, with $z_{n} \in\left[0, y_{0}\right)$ and $z_{n} \rightarrow y_{0}$. Now there exist $x_{3} \in X$ and a sequence $\left\{w_{n}\right\}$, with $w_{n} \in Y$, such that $x_{3} x_{2}=x_{1}$, and $x_{3} f\left(x_{2}, z_{n}\right)=f\left(x_{2}, z_{n}\right) w_{n}$. Now $\left\{z_{n} w_{n}\right\}$ is an increasing. sequence, and hence it must converge. Let $z_{n} w_{n} \rightarrow y_{1}$. Then $f\left(x_{1}, y_{0}\right)=f\left(x_{2}, y_{1}\right)$, and $0 \leqq y_{1}<y_{0}$. Hence $\left(x_{1}, y_{0}\right) \in J$. A similar argument shows $\left(x_{0}, y_{1}\right) \in J$ for $y^{1} \in\left[0, y_{0}\right)$.

Next let $\left(x_{1}, y_{1}\right) \in\left\{(x, y): 0 \leqq x \leqq x_{0}, 0 \leqq x \leqq y_{0}\right\} \backslash\left\{\left(x_{0}, y_{0}\right)\right\}$. Select $\left(x_{2}, y_{2}\right) \in\left\{(x, y): 0 \leqq x \leqq x_{0}, 0 \leqq y<y_{0}\right\}$ such that $f\left(x_{2}, y_{2}\right)=f\left(x_{1}, y_{1}\right)$. Now $\left(x_{2}, y_{0}\right) \in J$. Fix $y_{3} \in J$ such that $y_{0} y_{3}=y_{2} \quad$ By Lemma 7 there exists $x_{3} \in X$ such that $x_{3} f\left(x_{2}, y_{0}\right)=f\left(x_{2}, y_{0}\right) y_{3}$. Letting $x_{4}=x_{3} x_{2}$ we have $f\left(x_{4}, y_{0}\right)=f\left(x_{2}, y_{2}\right)=f\left(x_{1}, y_{1}\right)$.

CoRollary 9. If $(x, 1),(1, y) \in J$, then $x=0$ or $y=0$.

Proof. Since $(x, 1),(1, y) \in J$ there exist $x_{1} \in X, y_{1} \in Y$ such that $x_{1} f(x, 1)=f(x, 1) y$ and $x f(1, y)=f(1, y) y_{1}$. Thus $x_{1} x=y y_{1}$. This is impossible unless $x=0$ or $y=0$.

Lemma 10. Let $x \in X \backslash\{1\}, y \in Y$. Then $y x$ can be written as $x^{\prime} y^{\prime}$ with $x^{\prime} \in X \backslash\{1\}, y^{\prime} \in Y$.

Proof. If $y=0$ the result is clear. Thus we will assume $y \in$ $Y \backslash\{0\}$. We will divide the proof into several steps.

Step (1). Since $S=Y \cdot X=X \cdot Y$ we know that there exist $x_{1} \in$ $X \backslash\{1\}, y_{1} \in Y$ such that $y_{1} x_{1} \notin X \cup Y$, and thus there exist $x_{2} \in X \backslash\{1\}, y_{2}$ $\in Y$ such that $y_{1} x_{1}=x_{2} y_{2}$.

Step (2). Let $y_{3} \in Y$ with $y_{3} \geqq y_{1}$. Then there exists $y_{4} \in Y$ such that $y_{4} y_{3}=y_{1}$. Thus $y_{4} y_{3} x_{1}=y_{1} x_{1} \notin X \cup Y$. Hence $y_{3} x_{1} \notin Y$.

Step (3). We claim that for $y_{3} \in\left[y_{1}, 1\right]$ and $n$ a positive integer, $y_{3} x_{1}^{1 / n} \notin Y$. For if this were not the case there would exist a positive integer $n$ and a $y_{3} \in\left[y_{1}, 1\right]$ such that $y_{3} x_{1}^{1 / n}=y_{6} \in Y$. But by Lemma $2, y_{6}<y_{3}$. Thus there exists $y_{7} \in Y \backslash\{1\}$ such that $y_{7} y_{3}=y_{6}$. Hence $y_{3}\left(x_{1}^{1 / n}\right)^{n}=y_{3} x_{1}^{1 / n}\left(x_{1}^{1 / n}\right)^{n-1}=y_{6}\left(x_{1}^{1 / n}\right)^{n-1}=y_{7} y_{3}\left(x_{1}^{1 / n}\right)^{n-1}=\cdots=y_{7}^{n} y_{3} \in Y$. Thus $y_{3} x_{1} \in Y$. This is a contradiction.

Step (4). Let $x \in X \backslash\{1\}$. Then for $y_{3} \in\left[y_{1}, 1\right]$ we claim $y_{3} x$ can be represented as $x_{8} y_{8}$ with $x_{8} \in X \backslash\{1\}$, and $y_{8} \in Y$. Choose $n$ a positive integer such that $\left.x_{1}^{1 / n} \in[x, 1]\right)$. Then there exists $x_{9} \in X$ such that $x_{1}^{1 / n} x_{9}$ $=x$. Thus $y_{3} x=y_{3} x_{1}^{1 / n} x_{9}$. However, $y_{3} x_{1}^{1 / n} \notin Y$, and hence $y_{3} x$ can be written as $x_{8} y_{8}$ with $x_{8} \in X \backslash\{1\}$, and $y_{8} \in Y$.

Step (5). Finally, let $x \in X \backslash\{1\}$ and $y \in Y$. If $y=1$, then $y x=$ $x y$ and $x \in X \backslash\{1\}$ and $y \in Y$. If $y \in Y \backslash\{0,1\}$, then there exist a positive integer $m$ and $y_{3} \in\left[y_{1}, 1\right)$ such that $y=\left(y_{3}\right)^{m}$. Now $y x=\left(y_{3}{ }^{m} x=x^{\prime} y^{\prime}\right.$ with $x^{\prime} \in X \backslash\{1\}$, and $y^{\prime} \in Y$. 
The same argument can be used to show that if $x \in X$ and $y \in$ $Y \backslash\{1\}$, then $x y$ can be written as $y^{\prime} x^{\prime}$ with $x^{\prime} \in X$ and $y^{\prime} \in Y \backslash\{1\}$.

THEOREM 11. If $s \in S \backslash\{0\}$, then there exist unique $x \in X, y \in Y$ such that $x y=s$.

Proof. Suppose this is not the case. Then there exist $x_{1} \in X \mid\{0,1\}$, $y_{1} \in Y \backslash\{0,1\}$ such that $\left(x_{1}, y_{1}\right) \in J$. From corollary 9 we can assume $\{(1, y): y \in Y \backslash\{0\}\} \cap J=\phi$. Let $x_{2}=\sup \left\{x:\left(x, y_{1}\right) \in J\right\}$. Now $x_{2} \in(0,1)$ and $\left\{(x, y): 0 \leqq x \leqq x_{2}, 0 \leqq y \leqq y_{1}\right\} \backslash\left\{\left(x_{2}, y_{1}\right)\right\} \subset J$.

Next take $x_{3} \in\left(x_{2}, 1\right)$. Then there exist $x_{4} \in X \backslash\{0,1\}, y_{4} \in Y$ such that $y_{1} x_{3}=x_{4} y_{4}$. If $x_{4} \in\left(0, x_{2}\right]$, fix $x_{5} \in\left(x_{2}, x_{3}\right)$. If $x_{4} \in\left(x_{2}, 1\right)$, fix $x_{5} \in\left(x_{2}\right.$, $\left.\min \left\{x_{3}, x_{2} / x_{4}\right\}\right)$ where $x_{2} / x_{4}$ represents the unique element $p$ of $X$ such that $p x_{4}=x_{2}$. Take $y_{2} \in\left(y_{1}, 1\right)$. Then there exist $x_{6} \in X, y_{6} \in Y \backslash\{0,1\}$ such that $y_{2} x_{2}=x_{6} y_{6}$. If $y_{6} \in\left(0, y_{1}\right]$ fix $y_{7} \in\left(y_{1}, y_{2}\right)$. If $y_{6} \in\left(y_{1}, 1\right)$, fix $y_{7}$ $\in\left(y_{1}, \min \left\{y_{2}, y_{1} / y_{6}\right\}\right)$.

For each $x \in\left[x_{2}, x_{5}\right]$ we have $\left(x y_{1}\right)^{2}=x^{\prime} y^{\prime}$ with $x^{\prime} \in\left(0, x_{2}\right]$ and $y^{\prime} \in$ $\left(0, y_{1}\right]$. By lemma 8 there exists a unique $\bar{x} \in\left(0, x_{2}\right]$ such that $\left(x y_{1}\right)^{2}=$ $x^{\prime} y^{\prime}=\bar{x} y_{1}$. Hence we can define a function $x \rightarrow \bar{x}$ from $\left[x_{2}, x_{5}\right]$ into $\left(0, x_{2}\right]$. The function $x \rightarrow \bar{x}$ defined above is continuous and monotone and thus maps $\left[x_{2}, x_{5}\right]$ onto an interval $\left[\bar{x}_{2}, \bar{x}_{5}\right]$.

Also for $y \in\left[y_{1}, y_{7}\right]$ we have $\left(x_{2} y\right)^{2}=\widetilde{x} \widetilde{y}$ with $\tilde{x} \in\left(0, x_{2}\right]$ and $\tilde{y} \in$ $\left(0, y_{1}\right]$. Again by lemma 8 there exists a unique $x(y) \in\left(0, x_{2}\right]$ such that $\left(x_{2} y\right)^{2}=\tilde{x} \widetilde{y}=x(y) y_{1}$. Thus we can define a function $y \rightarrow x(y)$ from $\left[y_{1}, y_{7}\right]$ into $\left(0, x_{2}\right]$ which is continuous and monotone and hence maps $\left[y_{1}, y_{7}\right]$ onto an interval $\left[x\left(y_{1}\right), x\left(y_{7}\right)\right]$.

Now $\left(x_{2} y_{1}\right)^{2}=\bar{x}_{2} y_{1}$ and $\left(x_{2} y_{1}\right)^{2}=x\left(y_{1}\right) y_{1}$. Hence $\bar{x}_{2}=x\left(y_{1}\right)$, so the intervals $\left(\bar{x}_{2}, \bar{x}_{5}\right]$ and $\left(x\left(y_{1}\right), x\left(y_{6}\right)\right]$ intersect. Thus there exist $x \in\left(x_{2}, x_{5}\right]$ and $y \in\left(y_{1}, y_{7}\right]$ such that $\left(x y_{1}\right)^{2}=\left(x_{2} y\right)^{2}$. However, $\left(x, y_{1}\right) \notin J$, thus $x y_{1}$ $\neq x_{2} y$. This is a contradiction.

In the same manner we can show that each element $s \in S \backslash\{0\}$ can be written uniquely as $y x$ with $y \in Y$ and $x \in X$.

LEMMA 12. Let $T$ be a semigroup without zero divisors, $E(T)=$ $\{0,1\}$, and which is uniquely representable in terms of two usual threads $X$ and $Y$. Then $T \backslash\{0\}$ is cancellative.

Proof. Let $s, s_{1}, s_{2} \in T \backslash\{0\}$ with $s=x y, s_{1}=x_{1} y_{1}, s_{2}=x_{2} y_{2}$ with $x, x_{1}, x_{2} \in X, y, y_{1}, y_{2} \in Y$, and suppose $s s_{1}=s s_{2}$. Then $x y x_{1} y_{1}=x y x_{2} y_{2}$. Now let $y x_{1}=\bar{x}_{1} \bar{y}_{1}$ and $y x_{2}=\bar{x}_{2} \bar{y}_{2}$. Thus $x \bar{x}_{1} \bar{y}_{1} y_{1}=x \bar{x}_{2} \bar{y}_{2} y_{2}$. Since $T$ is uniquely representable we get that $\bar{x}_{1}=\bar{x}_{2}$ and thus $x_{1}=x_{2}$. This implies $\bar{y}_{1}=\bar{y}_{2}$ and hence $y_{1}=y_{2}$. Hence $s_{1}=s_{2}$. In the same manner we can show that if $s, s_{1}, s_{2} \in T \backslash\{0\}$ with $s_{1} s=s_{2} s$, then $s_{1}=s_{2}$. Thus 
$T \backslash\{0\}$ is cancellative.

CoROLlaRY 13. If $S$ is a uniquely divisible semigroup on the twocell with $E(S)=\{0,1\}$, then $S \backslash\{0\}$ is a cancellative semigroup.

\section{REFERENCES}

1. D. R. Brown, Topological semilattices on the two-cell, Pacific J. Math., 15 (1965), $35-46$.

2. D. R. Brown, and M. Friedberg, Linear Representations of certain compact semigroups, to appear.

3. E. E. DeVun, Special semigroups on the two-cell, Pacific J. Math., 34 (1970), 639-645.

4. Hildebrant, J. S., On uniquely divisible semigroups on the two-cell, Pacific J. Math., 23 (1967), 91-95.

5. Anne Lester Hudson, Some semigroups on the two-cell, Proc. Amer. Math. Soc., 10 (1959), 648-655.

Received December 10, 1969.

Wichita STATE UNIVERSITY 



\title{
PACIFIC JOURNAL OF MATHEMATICS
}

\author{
EDITORS
}

\author{
H. Samelson \\ Stanford University \\ Stanford, California 94305 \\ C. R. HOBBY \\ University of Washington \\ Seattle, Washington 98105
}

J. DugundJI

Department of Mathematics

University of Southern California

Los Angeles, California 90007

RICHARD ARENS

University of California

Los Angeles, California 90024

\section{ASSOCIATE EDITORS}

E. F. BECKENBACH
B. H. NEUMANN

F. WoLF
K. YosHIDA

\section{SUPPORTING INSTITUTIONS}

\author{
UNIVERSITY OF BRITISH COLUMBIA \\ CALIFORNIA INSTITUTE OF TECHNOLOGY \\ UNIVERSITY OF CALIFORNIA \\ MONTANA STATE UNIVERSITY \\ UNIVERSITY OF NEVADA \\ NEW MEXICO STATE UNIVERSITY \\ OREGON STATE UNIVERSITY \\ UNIVERSITY OF OREGON \\ OSAKA UNIVERSITY \\ UNIVERSITY OF SOUTHERN CALIFORNIA
}

\author{
STANFORD UNIVERSITY \\ UNIVERSITY OF TOKYO \\ UNIVERSITY OF UTAH \\ WASHINGTON STATE UNIVERSITY \\ UNIVERSITY OF WASHINGTON \\ $\stackrel{*}{*} \stackrel{*}{*} \stackrel{*}{*}{ }^{*}{ }^{*}$ MERICAN MATHEMATICAL SOCIETY \\ CHEVRON RESEARCH CORPORATION \\ NAVAL WEAPONS CENTER
}

The Supporting Institutions listed above contribute to the cost of publication of this Journal, but they are not owners or publishers and have no responsibility for its content or policies.

Mathematical papers intended for publication in the Pacific Journal of Mathematics should be in typed form or offset-reproduced, (not dittoed), double spaced with large margins. Underline Greek letters in red, German in green, and script in blue. The first paragraph or two must be capable of being used separately as a synopsis of the entire paper. The editorial "we" must not be used in the synopsis, and items of the bibliography should not be cited there unless absolutely necessary, in which case they must be identified by author and Journal, rather than by item number. Manuscripts, in duplicate if possible, may be sent to any one of the four editors. Please classify according to the scheme of Math. Rev. Index to Vol. 39. All other communications to the editors should be addressed to the managing editor, Richard Arens, University of California, Los Angeles, California, 90024.

50 reprints are provided free for each article; additional copies may be obtained at cost in multiples of 50 .

The Pacific Journal of Mathematics is published monthly. Effective with Volume 16 the price per volume (3 numbers) is $\$ 8.00$; single issues, $\$ 3.00$. Special price for current issues to individual faculty members of supporting institutions and to individual members of the American Mathematical Society: $\$ 4.00$ per volume; single issues $\$ 1.50$. Back numbers are available.

Subscriptions, orders for back numbers, and changes of address should be sent to Pacific Journal of Mathematics, 103 Highland Boulevard, Berkeley, California, 94708.

PUBLISHED BY PACIFIC JOURNAL OF MATHEMATICS, A NON-PROFIT CORPORATION

Printed at Kokusai Bunken Insatsusha (International Academic Printing Co., Ltd.), 7-17, Fujimi 2-chome, Chiyoda-ku, Tokyo, Japan. 


\section{Pacific Journal of Mathematics}

J. T. Borrego, Haskell Cohen and Esmond Ernest Devun, Uniquely

representable semigroups on the two-cell .................. 565

Glen Eugene Bredon, Some examples for the fixed point property ........ 571

William Lee Bynum, Characterizations of uniform convexity .......... 577

Douglas Derry, The convex hulls of the vertices of a polygon of order $n \ldots 583$

Edwin Duda and Jack Warren Smith, Reflexive open mappings .......... 597

Y. K. Feng and M. V. Subba Rao, On the density of $(k, r)$ integers ........ 613

Irving Leonard Glicksberg and Ingemar Wik, Multipliers of quotients of

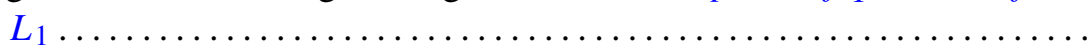

John William Green, Separating certain plane-like spaces by Peano

continua.........................................

Lawrence Albert Harris, A continuous form of Schwarz's lemma in normed

linear spaces .................................... 635

Richard Earl Hodel, Moore spaces and $w$-spaces ............... 641

Lawrence Stanislaus Husch, Jr., Homotopy groups of PL-embedding spaces.

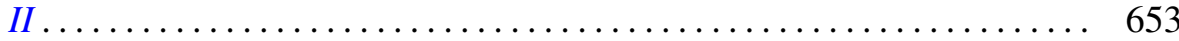

Yoshinori Isomichi, New concepts in the theory of topological

space-supercondensed set, subcondensed set, and condensed set.....

J. E. Kerlin, On algebra actions on a group algebra .................

669

Keizō Kikuchi, Canonical domains and their geometry in $C^{n} \ldots \ldots \ldots \ldots 681$

Ralph David McWilliams, On iterated $w^{*}$-sequential closure of cones. .

697

C. Robert Miers, Lie homomorphisms of operator algebras ..

717

Louise Elizabeth Moser, Elementary surgery along a torus knot ...

737

Hiroshi Onose, Oscillatory properties of solutions of even order differential

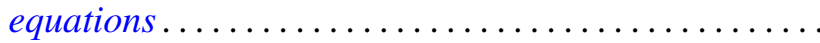

747

Wellington Ham Ow, Wiener's compactification and $\Phi$-bounded harmonic

functions in the classification of harmonic spaces...

Zalman Rubinstein, On the multivalence of a class of meromorphic

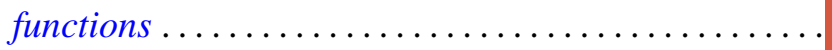

771

785

Hans H. Storrer, Rational extensions of modules

795

topological lattices ...........................

Robert Evert Stong, On the cobordism of pairs .................. 803
Albert Leon Whiteman, An infinite family of skew Hadamard matrices . . . 817

Lynn Roy Williams, Generalized Hausdorff-Young inequalities and mixed

norm spaces 